\title{
The molecular basis of metabolic cycles and their relationship to circadian rhythms.
}

\author{
Jane Mellor, Department of Biochemistry, South Parks Road, Oxford, OX1 3QU, UK
}

Abstract

Metabolic cycles result from the partitioning of oxidative and reductive metabolism into rhythmic phases of gene expression and oscillating post-translational modifications to proteins. Relatively little is understood about how the switches in gene expression are controlled during a metabolic cycle, although recent studies have suggested a central role for transcription itself, via extensive transcriptional interference involving non-coding transcription, in rhythmically switching genes on and off. This review explores the molecular basis of the metabolic and gene expression oscillations in the yeast, Saccharomyces cerevisiae, and how they relate to other biological time keeping mechanisms such as circadian rhythms.

\section{Introduction}

Biological oscillations, with frequencies ranging from milliseconds to years, play critical roles in the organisation of cellular physiology in virtually every organism, although their origins and regulation are not fully understood. The frequency of biological oscillations is determined by ultradian or time-keeping strategies that function in distinct but interconnected ways (Fig. 1).

First, there needs to be a clock to maintain actual time keeping, which is generally believed to be a biochemical oscillator. Good candidates are the non-transcriptional oscillators (NTOs), proteins that are regulated at the level of post-translational modifications, such as phosphorylation in cyanobacteria ${ }^{1}$ or oxidation-reduction (redox) cycles at cysteine residues of peroxiredoxins (PRXs), universally conserved from archaea to yeast to mammals ${ }^{2,3}$. The redox oscillators help to explain how rhythms are maintained in the absence of transcription and in anucleate cells, such as red blood cells ${ }^{4,5}$. A redox cycle is at the core of most oscillatory behaviour. In yeast and mammalian cells, interference with these redox cycles alters the period of an oscillation, but does not abolish it ${ }^{6}$. This is consistent with a clock function, but also supports the idea that additional regulatory components control the output of the clock, which is likely to be at the level of gene expression.

Gene expression oscillations are evident at three levels: in cycling levels of transcription, transcripts or proteins. These may be coordinated, but often are distinct, dependent on the varying inputs of post-transcriptional and post-translational control. For example, a cycling transcript may be associated with non-cycling protein levels, especially for proteins with a long half-life. The expression of many genes is controlled directly at the point of transcription by positive- and negative-acting transcription factors encoded by "clock genes", which create timedelayed negative feedbacks leading to oscillations, often described as transcriptional oscillations (TOs) ${ }^{7}$. However, in mammals and flies rhythmic production of some transcripts is maintained even when the factors proposed to mediated the positive or negative feedbacks are abolished, suggesting alternative inputs into transcriptional control, such as non-coding RNAs or metabolites ${ }^{6,8,9}$. In addition to transcriptional control of cycling transcripts, many are now known to be controlled post-transcriptionally, although the precise mechanisms are not understood $^{10-16}$. Finally, levels of a limited number of proteins oscillate independently of their 
transcripts ${ }^{17-19}$. Interestingly, BMAL, a "clock protein" first described as a transcription factor also regulates translation ${ }^{20}$.

Biological time keeping strategies are also intimately linked with metabolite oscillations. Metabolite concentrations fluctuate at the cellular ${ }^{21-23}$ and organismal level ${ }^{24,25}$, which reflects, facilitates and interconnects the redox changes and cycling patterns of gene expression underlying biological rhythms ${ }^{8}$. The potential connections between the time-keeping mechanisms and metabolism is an important current area of research, especially given the explosion of metabolically-related conditions, such as diabetes, obesity, cancer and cardiovascular disease linked to lifestyles lacking regular patterns of eating, sleeping and exercise, which would normally be coordinated by cellular clocks ${ }^{26}$. In mammals, the activity of "clock proteins" is regulated by metabolites while the production of metabolites is, itself, controlled by oscillating gene expression ${ }^{27}$. Thus, NAD-dependent enzymes, nutrient-sensing regulatory proteins, redox-controlled transcription factors, lysine acetyl transferases and protein kinases are likely to mediate the links between cellular metabolism and biological oscillations ${ }^{8}$.

The single cell eukaryote Saccharomyces cerevisiae can temporally partition its metabolism into distinct rhythmic phases of gene expression, known as the yeast metabolic cycle (YMC) or, alternatively, yeast respiratory oscillations (YROs), offering a powerful system in which to study interconnections between metabolism, rhythmic gene expression and biological cycles. This review will outline the recent advances in our understanding of the YMC, its relationship to rhythms in other organisms, particularly the circadian 24-hour rhythm, and the role of transcription in regulating the YMC.

\section{The yeast metabolic cycle}

A metabolic cycle is a global partitioning of metabolism, regulated by an ultradian clock, coordinating mitochondrial energetics and the redox balance in the cells, with transcriptional regulation, mitochondrial structure, DNA replication and the cell division cycle (CDC). The metabolic cycle in the budding yeast S.cerevisiae, studied for over 45 years $^{28}$, is a robust ultradian rhythm in oxygen consumption that synchronises spontaneously when cells are grown at high density in aerobic, nutrient-limited continuous culture, respiring the available glucose ${ }^{28-}$

${ }^{34}$ (Fig. 2). Cycling is assessed by levels of dissolved oxygen $\left(\mathrm{dO}_{2}\right)$ in the medium, describing two distinct phases known as the high oxygen consumption phase $(\mathrm{HOC})$, interspersed with a period of lower oxygen consumption (LOC).

Metabolic cycles with distinct lengths have been studied in yeast, a short phase cycle (approx. 40 mins) and a long phase cycle (4-5 hours) that reflect the available glucose and differ in the degree to which the $\mathrm{CDC}$ is synchronised with the metabolic cycle, being greater for the long phase $\mathrm{YMC}^{31,35-38}$. The oxidative bursts during the $\mathrm{HOC}$ are not merely a function of the $\mathrm{CDC}$, as metabolic cycling can occur in the absence of a $\mathrm{CDC}^{32}$, but rather the $\mathrm{CDC}$ and the YMC should be thought of as coupled oscillators that work together to ensure DNA replication and cell division occur only when sufficient cellular energy reserves have accumulated in the LOC. The cyclin dependent kinase (CDK) couples 'Start', the point at which the cell becomes committed to entering the $\mathrm{CDC}$, to the initiation of the oxidative burst (HOC). At this point there is a rapid increase in intracellular glucose, as a result of mobilization of glycogen and trehalose stores ${ }^{35,36}$, which is metabolised using both respiration and aerobic fermentation, accompanied by 
increased $\mathrm{O}_{2}$ uptake from the medium (the $\mathrm{HOC}$ ), increased production of $\mathrm{CO}_{2}$, and secretion of ethanol ${ }^{28}$, acetate, acetaldehyde and hydrogen sulphide. These secretions help maintain synchrony ${ }^{37-39}$ and are assimilated in the subsequent LOC when carbohydrate stores are replenished.

Regardless of the phase length, the YMC is characterised by cycling transcripts ${ }^{30,31,40,41}$ with a robust common cohort that form two superclusters encoding for growth and anabolism during the HOC and mitochondrial growth, catabolism and stress resistance during the LOC ${ }^{42}$. ATP:ADP ratios also oscillate with these transcript superclusters, reflecting their potential to encode alternative metabolic activities and thus alter the energetic state of the cell ${ }^{42}$ (Fig. 2). It is estimated that more than 4,500 transcripts can show periodic expression (greater than $70 \%$ of the transcribed genes), although numbers vary depending on growth conditions (more transcripts cycle in high glucose compared to low glucose conditions) $)^{43}$ and on the bioinformatics used to assess cycling ${ }^{44}$.

\section{Why cycle transcripts?}

Although the NTOs maintain rhythms without the need for transcription, it is generally believed that gene expression cycles play an essential role under most circumstances and that TOs and NTOs are likely to be interconnected to robustly sustain cellular rhythms ${ }^{45}$. The most obvious answer to the question of "why cycle transcripts?" is to temporally partition incompatible processes promoted by the proteins translated from these transcripts. Yeast show remarkable compartmentalisation of their gene expression during the HOC and LOC phases of YMC that broadly reflects anabolic and catabolic metabolism ${ }^{31,41,42}$. In Neurospora, metabolic genes are the most significantly associated with the circadian cycle ${ }^{13,46}$. In mice and flies, temporal compartmentalisation of metabolic functions also takes place during their circadian cycle ${ }^{12,47,48}$ and there is now clear evidence for a human circadian metabolome reflecting cyclical metabolic processes $^{24,25}$.

A second compelling argument for cycling genes in these diverse systems is that they define a conserved mechanism for cellular energy conservation. Cycling genes are often the "costliest" to transcribe and translate as they are frequently expressed at high levels. Cycling reduces the costs involved ${ }^{43}$, because abundant proteins can be synthesised when they are needed and downregulated when they are not. These ideas have led to the concept of a "just-in-time" strategy to deliver components exactly when they are needed ${ }^{41}$, which has the net effect of allowing cells to flexibly adapt to their environment. This responsiveness can be seen when spiking a yeast culture with a carbon source such as acetate, which is sufficient to rapidly advance cells into the HOC growth phase ${ }^{37}$. Thus both yeast and mammalian systems use molecular time-keeping strategies, involving cycling transcripts, to integrate their cellular functions ${ }^{43,49}$.

\section{How do metabolic cycles relate to circadian and ultradian rhythms?}

Circadian rhythms, controlled by endogenous circadian clocks, are rhythmic oscillations with a period close to $24 \mathrm{~h}$ that synchronise biochemical, metabolic, physiological and behavioural 
cycles, allowing adaptation to changing light and temperature caused by rotation of the earth ${ }^{27}$. Despite the fact that "clock" genes and proteins are not conserved, circadian rhythms occur in diverse organisms ranging from bacteria and fungi to plants and animals ${ }^{50}$. It has been proposed that a circadian rhythm is fundamentally a metabolic cycle with additional time keeping mechanisms ${ }^{51,52}$. Therefore, the ultradian metabolic cycle in yeast should share properties with circadian clocks. Supporting this hypothesis, it has been shown that perturbations to casein kinase 1 or GSK3 $\beta$ that affect the period of circadian rhythms in cultured mammalian cells, also have similar effects on YMC periodicity (Table I). Similarly, the NTOs, particularly the peroxiredoxins, conserved between yeast and mammalian cells, undergo cycles of oxidation during the $\mathrm{YMC}$ and their modulation results in periodicity changes to the $\mathrm{YMC}$ and to circadian rhythms ${ }^{6}$. Taken together, these observations suggest a similar origin of the YMC and the circadian rhythms of mammals, although it is possible that enzymes such as CK1 and GSK3 $\beta$ do not have a specific function in the circadian clock/YMC but a more general function in cells that indirectly affect these rhythms. Interestingly, periodicity of the non-circadian daily tidal rhythms in Eurydice pulchra is also influenced by $\mathrm{CK} 1^{53}$.

140 Remarkably, budding yeast can also display a circadian clock when entrained with temperature

141 variations to mimic day/night cycles ${ }^{54,55}$. Perhaps the once-dominant circadian period has been modified to enhance fitness by shortening the period of oscillation, allowing a faster CDC, rapid growth, while maintaining temporal separation of metabolism. The shared features of TOs and NTOs in yeast and mammalian cells might reflect metabolic oscillations as the primitive mechanism on which circadian and ultradian oscillators of modern organisms have been built, including sleep-wake cycles and hibernation ${ }^{52}$, with metabolic cycles being the origins of biological timekeeping ${ }^{56}$, proposed to be a basic universal necessity for fitness by coordinating intracellular metabolism ${ }^{49}$.

\section{Factors that alter the periodicity of the YMC or abolish cycling.}

Although there has not yet been a comprehensive genome-wide analysis of genes that influence cycling, currently available data highlight a number of major processes including glutathione 57 and peroxiredoxins ${ }^{6}$ redox reactions; ethanol assimilation pathways ${ }^{58}$; sulphur metabolism (cysteine oxidation and reduction by thioredoxins; thiolation of tRNAs; sulphur metabolism) ${ }^{6,59,60}$; synthesis of the cycling metabolite $\mathrm{NADPH}^{22}$; acetylation of histone proteins using the cycling metabolite acetyl-CoA ${ }^{37,41}$; changes to the $\mathrm{CDC}^{6,60}$; and finally links to growth rate $^{35,43}$ (Table II).

Metabolic cycling is sensitive to growth conditions, particularly glucose concentration. In the chemostat, with constant environmental conditions, yeast reach steady-state at a specific growth rate and $C D C^{61}$, that can be changed by altering the rate at which the culture is diluted with fresh medium. Thus, altering the dilution rate changes the YMC period, effectively by changing the concentration of available glucose. Free glucose levels are almost zero as cells absorb and metabolise the available glucose almost immediately. Each prototrophic strain has a predictable response, and as the dilution rate decreases (lower available glucose) there is an increase in the period of the YMC that is primarily the LOC phase while the HOC phase remains the same or shortens ${ }^{33,35}$. Thus the YMC is not fixed but shows plasticity enabling adaptation to 
changing conditions (Fig. 3). Changes to growth rate by limiting different nutrients produces a common signature of HOC and LOC genes whose expression changes ${ }^{62}$. This growth-related common gene expression signature is also observed in strains carrying gene deletions that reduce growth rate, particularly non-essential genes with nuclear-related functions ${ }^{63}$. These cells spend more time in G0/G1 and show reduced HOC transcripts, associated with growth, and increased LOC transcripts, particularly associated with the environmental stress response (ESR). Put simply, the ESR in yeast reflects a reduced growth rate, changes to the CDC and concomitant changes in the proportion of cells in the population expressing HOC or LOC-related genes, even in exponentially growing batch cultures. These indirect but dramatic changes in levels of thousands of transcripts, simply as a result of interventions that change growth rate, reveal how closely the metabolic cycling transcripts are related to growth and the CDC. This hard-learnt lesson from yeast physiology should be considered by those interfering with genes and gene expression in other organisms, as it is likely that many of the changes in gene expression observed also reflect the indirect effects of altering growth rates.

The changes to the YMC period that result from mutations in genes encoding CDC regulators are somewhat paradoxical in light of the growth-related signature discussed above, as growthretarded cell cycle mutants often exhibit a YMC with reduced cycle length rather than lengthened as expected ${ }^{6,60}$. This difference is rationalised as a faster $Y M C$, with reduced period, presenting more openings for the cells to attempt to enter the CDC and suggests decoupling of the normally tight links between the YMC and the CDC. However, these data are based solely on dissolved $\mathrm{O}_{2}$ as the indicator of metabolic state and cannot be fully understood until gene expression changes are also assessed.

Levels of NADPH reflect the ability of the cell to protect itself from oxidative stress ${ }^{64}$, explaining the high levels of NADPH as cells enter the HOC. Addition of exogenous methionine to cells increases their tolerance to oxidative stress and improves ageing, related to changes in the flux through the oxidative branch of the pentose phosphate pathway and increased levels of $\mathrm{NADPH}^{65}$. The zwf1 mutant, that fails to produce high levels of NADPH, also fails to cycle, suggesting an additional signalling role for NADPH in metabolic cycling.

Levels of acetyl-COA and NADPH peak during the HOC of the YMC. Apart from its role as a central metabolite, acetyl-CoA is also the co-factor for protein acetylation ${ }^{66}$. Levels of acetyl-CoA are likely to reflect the energy state of the cells ${ }^{67}$ and coordinate entry into the YMC and CDC ${ }^{68}$. Gcn5, an acetyl-CoA-dependent lysine acetyltransferase (KAT), is required for metabolic cycling. Although $\mathrm{Gcn} 5$ acetylates multiple proteins, its acetylation of histones $\mathrm{H} 3$ and $\mathrm{H} 4$ plays a key role in metabolic cycling, as amino acid substitutions at acetylatable lysine prevents cycling ${ }^{41}$. This also implicates transcriptional regulation in metabolic cycling, through direct changes to chromatin.

\section{Transcriptional regulation of the YMC}

Many of the recent studies on transcriptional regulation of the YMC, use the long phase cycle and refer to three major phases, defined by gene clusters with similar gene ontology, known as oxidative (OX), reductive/building phase (RB) and reductive/charging $(R C)^{31,41}$. When these phases were named, it was assumed that dip in $\mathrm{d}\left[\mathrm{O}_{2}\right]$ correlated with respiration predominantly in the OX phase, although it has long been known that respiration occurs throughout the YMC 
but increases, together with glycolysis, in the OX and part of the RB phases (equivalent to the $\mathrm{HOC})^{34}$. Thus these terms can easily be misconstrued, but as each phase shows distinctive

211 features, OX, RB and RC will be used here (Fig. 3).

212 Three important studies linking nucleosome positioning ${ }^{69}$ or post-translational modifications of 213 histones ${ }^{37,41}$ to cycling transcripts in the YMC, reveal that chromatin is globally altered as cells 214 progress through the YMC. In the RC phase (approximately defining the LOC), nucleosomes are evenly spaced and many nucleosome depleted regions become occupied ${ }^{69}$, although there is
correlation with transcript levels. The transition from RC to OX is accompanied by significant remodelling of OX promoter nucleosomes by the SWI/SNF chromatin remodelling ATPase, opening the chromatin and allowing the transcription machinery access to the transcriptional start site (TSS). Histone H3 lysine acetylation, particularly at H3K9 and H3K18, peaks in the OX and RB phase ${ }^{37}$, concomitant with the peak in global acetyl-CoA levels ${ }^{22}$, and acetylation of chromatin at individual promoters ${ }^{41}$. However, modifications such as $\mathrm{H} 3 \mathrm{~K} 4 \mathrm{me} 3$, peak on OX genes after the $\mathrm{OX}$ transcripts appear ${ }^{41}$ suggesting that not all modifications are instructive for transcription, as widely believed. Indeed, methylation of H3K4 is required for the repression of some OX genes, particularly ribosomal protein genes (RPGs) ${ }^{70,71}$.

At OX genes, promoter nucleosome repositioning correlates with the appearance of transcripts. This implies that reversal of this opening would correlate with OX gene repression. As mentioned, SWI/SNF is strongly enriched at OX genes, particularly at RPGs ${ }^{72}$ that are also regulated by the Ifh1 transcription factor. The functions of SWI/SNF and Ifh1 are negatively regulated by Gcn5-dependent acetylation ${ }^{73,74}$. Thus, the peak of acetyl-CoA might coordinate both the activation and subsequent repression of OX genes, by first facilitating and then preventing chromatin remodelling.

Acetylation-dependent neutralisation of the positive charges on $\mathrm{H} 3$ and $\mathrm{H} 4$ may also play a regulatory role. Strains with $\mathrm{H} 3 \mathrm{~K} 9,14,18 \mathrm{R}$ substitutions show increased $\mathrm{O}_{2}$ consumption in batch cultures $^{75}$ and a YMC with decreased period ${ }^{41}$, indicating more frequent OX phases. This supports a role for chromatin modifications and nucleosome repositioning in repressing OX genes, and the ability to repress OX genes may be essential for metabolic cycling. RB genes also appear to be regulated by chromatin-mediated effects, as strains with reduced histone expression or defects in chromatin assembly show increased respiration and expression of a selection of RB genes including those that control mitochondria ${ }^{75}$. By contrast, RC genes, show no correlation between promoter nucleosome occupancy and transcript levels; rather, nucleosome depleted regions acquire nucleosomes in the RC phase at regions of the genome that also function as boundary elements separating chromosomally interacting domains (CIDs), similar to topologically associated domains in mammals ${ }^{76}$. This suggests that CID boundaries are reconfigured by nucleosomes as cells enter RC. Note that some cells will have undergone mitosis, with marked chromatin condensation immediately prior to entering RC, perhaps explaining this re-organisation. Thus, $\mathrm{OX}$ and $\mathrm{RC}$ genes have very different requirements for expression, in terms of chromatin re-organisation. Interestingly, the nucleotide content of OX and $\mathrm{RC}$ genes is markedly different ${ }^{42}$. Since nucleosomes have certain sequence preferences ${ }^{77,78}$, these differences might underpin their differential regulation by nucleosomes ${ }^{42}$.

It is likely that transcription factors (TFs) are required to facilitate chromatin opening at OX genes. Indeed, a detailed study of a cluster of YMC-regulated genes revealed OX gene activation 
requires specific transcription factors, while RC genes have the capacity to be induced in OX growth conditions, suggesting that at least for the genes studied, phase-specific factors are not required for $\mathrm{RC}$ expression ${ }^{15}$. In mammals, there is dynamic promoter chromatin opening during circadian rhythms and the BMAL TF, which behaves as a pioneer factor, shifts +1 nucleosome positions at many genes, including genes that are not immediately induced ${ }^{79}$. This is interpreted as an anticipation of potential events, endowing genes with the capacity to cycle, dependent on conditions. This is somewhat reminiscent of the YMC, where the number of genes that cycle changes with varying conditions ${ }^{35,43}$. It also suggests that additional signals or factors control the precise timing of transcription at individual genes and can function once the chromatin structure is permissive. Chromatin opening is likely to be a crucial component of the rhythmic timing, as flies with enhanced levels of CYC and CLOCK (equivalent to mammalian BMAL and CLOCK) have increased levels of per mRNA and short periods ${ }^{80,81}$. In the YMC, there is no evidence as yet for a master transcriptional regulator, or set of regulators such as the BMAL/CLOCK/PER/REV-ERB/CRY circadian regulators in mammals, that would bring about transcript oscillations ${ }^{82}$. Nevertheless, transcripts encoding many TFs are known to cycle and peak at all phases of the $\mathrm{YMC}^{31,39}$. If these cycling transcript are associated with cycling levels of the functional protein, then there is plenty of scope for phase-specific transcriptional regulation during the YMC. However, analysis of TFs during the YMC will require a better understanding of which cycling transcripts are actually regulated directly at the level of transcription.

As yet there is no published data on cycling transcription, as opposed to transcripts, during the YMC. However, there is a data set on nascent transcription obtained using NET-seq for yeast growing in glucose and then switched to galactose that may act as a proxy for genes subject to transcriptional regulation during the $\mathrm{YMC}^{15}$. In addition to the twelve genes expected to be induced on galactose, and required to catabolise galactose, nearly a thousand genes show a $>3-$ fold change in their transcription upon the switch. Curiously, transcripts of the genes regulated by the glucose to galactose shift also cycle in the OX and RC phases the YMC ${ }^{15}$ (Fig. 4).

Further analysis of the relationship between YMC-regulated genes reveals that their position in the genome is not random and that there is extensive co-regulation ${ }^{15}$. For example, OX genes are highly expressed in glucose, while RC genes are more highly expressed in galactose. Moreover, RC genes are actively repressed in glucose, especially when organised in tandem with an upstream OX gene. This provides a mechanism by which transcripts of RC genes might cycle due to direct transcriptional interference from OX genes. In fact, genome-wide analysis reveals common features of such tandem clusters, particularly OX:RC pairs: reciprocal transcription in glucose and galactose conditions; reciprocally cycling transcripts in the YMC; di-cistronic transcripts spanning $\mathrm{OX}$ and $\mathrm{RC}$ genes; and reciprocal antisense (as) transcription to OX genes spanning the OX gene promoter (Fig. 4). These features contribute to a bimodal switch whereby transcription itself, via transcriptional interference, switches OX genes on and RC genes off or vice versa, depending on growth conditions. Mechanistically, di-cistronic transcription over a promoter region leads to Set2-dependent H3K36 methylation, which by signalling histone deacetylation ${ }^{83,84}$, represses transcription.

There is also evidence for histone modifications influencing rhythms and clocks in other organisms. In Neurospora, the H3K36 methyltransferase, SET-2, is rhythmically associated with the master regulator gene frequency (frq) to suppress its expression, and thus influence clock 
function $^{85}$. As with yeast, SET-2 is likely to bring about histone deacetylation, as strains expressing $\mathrm{H} 3$ with $\mathrm{K} 9,14,18$ substituted with $\mathrm{Q}$, to mimic the acetylated state, also show a defective clock. Furthermore, as with many of the YMC clusters that show bimodal transcription and switching, frq transcription is regulated by transcription of the antisense transcript $q r f$, which oscillates antiphase to frq RNA. In addition, the two transcription units show mutual inhibition ${ }^{86}$, just as observed for the yeast OX gene HMS2 and its antisense transcript SUT650 ${ }^{15}$. Indeed cycling non-coding transcripts may be a general feature of clocks and rhythms in many different organisms, including mammals (asPer2) ${ }^{10,87,88}$, silkmoth (asPER) ${ }^{89}$ and plants (COOLAIR, antisense to $F L C)^{90}$. Antisense transcription is known to bring about a distinct chromatin structure at sense promoters ${ }^{91}$ that could explain these state switches during rhythms. Moreover, if the acts of antisense and sense transcription are mutually exclusive in individual cells, supported by RNA fluorescence in situ hybridization (FISH), which reveals that at a number of loci cells express sense or antisense transcripts but generally not both ${ }^{92}$, then even the production of a short antisense transcript could limit sense transcription during cycles.

\section{Summary and perspectives}

\section{What do we NOT know about the YMC?}

Our understanding of the molecular events in the YMC is based predominantly on cycling transcripts but how these transcripts cycle (whether they are subject to transcriptional and/or post-transcriptional regulation) and whether transcript cycling affects the proteome or posttranslational modifications to the proteome remain to be rigorously addressed. Understanding the relationship between nascent transcription and transcripts will aid in the search for key transcription factors that drive the YMC. A detailed proteome will allow post-translational modifications to proteins to be defined more precisely and give a better understanding of the range of biochemical oscillators in yeast and importantly how they relate to the redox state of the cell and available metabolites. Single-cell studies will enhance our ensemble view of the YMC. Once these features are in place, the YMC will provide an unprecedented view of gene expression and metabolism in a synchronised time-resolved population of cells and undoubtedly shed light on fundamental processes that impact on ageing and metabolic diseases where rhythms are compromised.

\section{Acknowledgements}

This work was funded by the BBSRC (BB/J0054X/1), The Wellcome Trust (089156) and EC FP7 EpiGeneSys. Many thanks to Françoise Howe, Ronja Woloszczuk, Andrew Angel, all member of the Mellor laboratory and the reviewers for their comments. 

in cultured cells

\begin{tabular}{|c|c|c|}
\hline Feature & Yeast Metabolic Cycle & Circadian Rhythm in cultured cells \\
\hline Coupled with CDC & $\begin{array}{l}\text { YMC can occur without } \mathrm{CDC}^{32} \\
\text { Swe1 alters cycle length } \\
\text { Long phase } \mathrm{YMC} \text { is synchronised to } \\
\mathrm{CDC}^{28}\end{array}$ & $\begin{array}{l}\text { Oscillations are coupled with the } \\
C D C \text { in mouse embryonic } \\
\text { fibroblasts }{ }^{6,93}\end{array}$ \\
\hline $\begin{array}{l}\text { Temperature-compensated cycle } \\
\text { (cycling is robust, despite changes } \\
\text { in temperature) }\end{array}$ & $\begin{array}{l}\text { In yeasts, S.cerevisiae and S. pombe } \\
29,94,95\end{array}$ & In mouse embryonic fibroblasts ${ }^{96}$ \\
\hline Redox and metabolic cycles & $\begin{array}{l}\text { Glucose concentration influences } \\
\text { cycle length } \\
\text { Mitochondrial metabolism } \\
\text { Redox balance involving } \\
\text { NADPH } \\
\text { Redox balance involving } \\
\text { glutathione and GSH } \\
\text { Peroxiredoxin over-oxidation cycle }\end{array}$ & $\begin{array}{l}\text { Glucose utilization in ESCs }{ }^{56} \\
\text { Mitochondrial metabolism } \\
\text { Metabolic events in erythrocytes, } \\
\text { fibroblasts and myoblasts } \\
\text { Peroxiredoxin over-oxidation } \\
\text { cycle }^{6,103}\end{array}$ \\
\hline Rhythmic gene expression (TOs) & $\begin{array}{l}\text { Rhythmic transcripts }{ }^{30,31,41,97} \\
\text { Rhythmic chromatin modifications } \\
37,41,42 \\
\text { Rhythmic nucleosome positioning }\end{array}$ & $\begin{array}{l}\text { Rhythmic transcripts and chromatin } \\
\text { modifications } \\
\text { 10,106-109 }\end{array}$ \\
\hline Cell autonomous cycling & $\begin{array}{l}\text { Condition and strain-dependent } \\
\text { constant periods } s^{31,55,94,97,101} \text {. }\end{array}$ & $\begin{array}{l}\text { In mouse embryonic fibroblasts }{ }^{93} \\
\text { In neurons }{ }^{110}\end{array}$ \\
\hline Shared determinants of clock speed & GSK3 and CK1 ${ }^{6}$ & GSK3 and $\mathrm{CK} 1^{6}$ \\
\hline
\end{tabular}

Table II: Factors that alter the periodicity of the YMC or abolish cycling.

\begin{tabular}{|c|c|c|c|}
\hline Factor or intervention & Effect on the YMC & Comment & Reference \\
\hline$g c n 5 \Delta$ & Abolished & $\begin{array}{l}\text { Lysine acetyltransferase uses } \\
\text { acetyl CoA, a key cycling } \\
\text { metabolite, as cofactor. }\end{array}$ & 37 \\
\hline H3К $(9,14,18,23,27) \mathrm{R}$ & Abolished & $\begin{array}{l}\text { Arginine }(R) \text { substitutions at } \\
\text { lysines at positions } 9,14,18,23 \\
\text { and } 27 \text { on histone } H 3 \text {, subject to } \\
\text { acetylation, some by Gcn5. }\end{array}$ & 41 \\
\hline $\mathrm{H} 4 \mathrm{~K}(5,8,12) \mathrm{R}$ & Abolished & $\begin{array}{l}\text { Arginine }(R) \text { substitutions at } \\
\text { lysines at positions } 5,8 \text { and } 12 \text { on } \\
\text { histone } H 4 \text {, subject to acetylation. }\end{array}$ & 41 \\
\hline $\mathrm{H} 3(\mathrm{~K} 9,14,18,23,27) \mathrm{A}$ & Decreases YMC period & $\begin{array}{l}\text { Alanine }(A) \text { substitutions at lysines } \\
\text { at positions } 9,14,18,23 \text { and } 27 \\
\text { on histone } H 3 \text {, subject to } \\
\text { acetylation, some by Gcn5. }\end{array}$ & 41 \\
\hline $\mathrm{H} 4(5,8,12) \mathrm{A}$ & Decreases YMC period & $\begin{array}{l}\text { Alanine }(\mathrm{A}) \text { substitutions at lysines } \\
\text { at positions } 5,8 \text { and } 12 \text { histone } \mathrm{H} 4 \text {, } \\
\text { subject to acetylation. }\end{array}$ & 41 \\
\hline $\operatorname{sgf} 73 \Delta$ & $\begin{array}{l}\text { Unstable YMC with } \\
\text { short period }\end{array}$ & $\begin{array}{l}\text { Anchors a deubiquitinase module } \\
\text { into SAGA and SLIK complexes } \\
\text { also containing Gcn5; deletion } \\
\text { shows reduced levels of H3K9ac; }\end{array}$ & 37 \\
\hline
\end{tabular}




\begin{tabular}{|c|c|c|c|}
\hline & & $\begin{array}{l}\text { sgf } 73 \Delta \text { exhibited an abnormal RB } \\
\text { phase during which cells exhibit a } \\
\text { second burst of oxygen } \\
\text { consumption }\end{array}$ & \\
\hline ada3 $\Delta$ & $\begin{array}{l}\text { Unstable YMC with } \\
\text { short period }\end{array}$ & $\begin{array}{l}\text { Required for Gcn5-dependent } \\
\text { lysine acetylation, deletion shows } \\
\text { reduced levels of H3K9ac; ada3 } \\
\text { exhibit a shorter HOC phase }\end{array}$ & 37 \\
\hline PF670462 & Increases YMC period & $\begin{array}{l}\text { Inhibitor of CK } 1 \delta \text {; also increases } \\
\text { period of mammalian circadian } \\
\text { clock. }\end{array}$ & 6 \\
\hline LH846 & Increases YMC period & $\begin{array}{l}\text { Inhibitor of CK1€; also increases } \\
\text { period of mammalian circadian } \\
\text { clock. }\end{array}$ & 6 \\
\hline $\operatorname{rim} 11 \Delta$ & Decreases YMC period & $\begin{array}{l}\text { GSK3 } \beta \text { Ser/Thr kinase homologue; } \\
\text { knockdown of homologue also } \\
\text { reduces periodicity of mammalian } \\
\text { circadian clock. }\end{array}$ & 6 \\
\hline 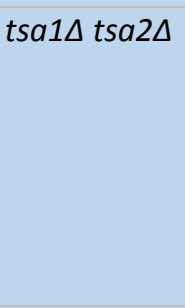 & Decreases YMC period & $\begin{array}{l}\text { Cytosolic peroxidoredoxins (PRXs), } \\
\text { thiol-specific peroxidases, Tsa1 } \\
\text { shows cysteine over-oxidation } \\
\text { ( } \mathrm{SO}_{2 / 3} \text { ) peaking just after } \mathrm{HOC} \\
\text { phase when free radicals are high. } \\
\text { Single deletions have no effect on } \\
\text { YMC. }\end{array}$ & 6 \\
\hline $\operatorname{prx} 1 \Delta$ & Increased YMC period & Mitochondrial peroxidoredoxin. & \\
\hline swe $1 \Delta^{* *}$ & Decreases YMC period & $\begin{array}{l}\text { Ser/Thr kinase. Homologue of } \\
\text { tumour suppressor gene WEE1, } \\
\text { deletions grow more slowly, acts } \\
\text { at G2/M and G1 phases of CDC. } \\
\text { YMC and CDC remain coupled in } \\
\text { deletion but the cell cycle is } \\
\text { longer and fewer cells enter HOC } \\
\text { phase at any point in time. } \\
\text { Mammalian cancer cells also show } \\
\text { a wider range of circadian timings. }\end{array}$ & 6 \\
\hline $\operatorname{cln} 1 \Delta$ & $\begin{array}{l}\text { Slightly increases YMC } \\
\text { period }\end{array}$ & $\begin{array}{l}\text { G1 cyclin involved in regulation of } \\
\text { the cell cycle; activates } \mathrm{Cdc} 28 \mathrm{p} \\
\text { kinase to promote the } \mathrm{G} 1 \text { to } \mathrm{S} \\
\text { phase transition; no growth defect }\end{array}$ & 60 \\
\hline bub1 $1 \Delta^{* *}$ & Decreases YMC period & $\begin{array}{l}\text { Protein kinase involved in the cell } \\
\text { cycle checkpoint into anaphase; in } \\
\text { complex with Mad1p and Bub3p, } \\
\text { prevents progression into } \\
\text { anaphase in presence of spindle } \\
\text { damage }\end{array}$ & 60 \\
\hline $\operatorname{cdh} 1 \Delta^{* *}$ & Decreases YMC period & $\begin{array}{l}\text { Activator of anaphase-promoting } \\
\text { complex/cyclosome (APC/C) }\end{array}$ & 60 \\
\hline swi6 $\Delta^{* *}$ & Decreases YMC period & $\begin{array}{l}\text { Transcription cofactor; forms } \\
\text { complexes with Swi } 4 p \text { and Mbp1p } \\
\text { to regulate transcription at the } \\
\text { G1/S transition }\end{array}$ & 60 \\
\hline bem $2 \Delta^{* *}$ & Decreases YMC period & $\begin{array}{l}\text { Rho GTPase activating protein } \\
\text { (RhoGAP); involved in the control } \\
\text { of cytoskeleton organization and } \\
\text { cellular morphogenesis; required } \\
\text { for bud emergence }\end{array}$ & 60 \\
\hline $\operatorname{sic} 1 \Delta^{* *}$ & Decreased/almost & Cyclin-dependent kinase inhibitor & 60 \\
\hline
\end{tabular}




\begin{tabular}{|c|c|c|c|}
\hline & abolished & $\begin{array}{l}\text { (CKI); inhibitor of } \mathrm{Cdc} 28-\mathrm{Clb} \text { kinase } \\
\text { complexes that controls } \mathrm{G} 1 / \mathrm{S} \\
\text { phase transition }\end{array}$ & \\
\hline $\operatorname{rad53\Delta } \mathrm{sm} / 1 \Delta^{* *}$ & Abolished after 4 cycles & $\begin{array}{l}\text { Essential DNA damage response } \\
\text { protein kinase; required for cell- } \\
\text { cycle arrest in response to DNA } \\
\text { damage, viable in absence of } \\
\text { Sml1, homologue of prd-4 } \\
\text { required for circadian rhythms in } \\
\text { Neurospora crassa. }\end{array}$ & 60 \\
\hline $\begin{array}{l}\text { Reduced dilution rate in } \\
\text { chemostat }\end{array}$ & Increases YMC period & $\begin{array}{l}\text { As growth rate decreases, the } \\
\text { period of the YMC and the time } \\
\text { spent in the LOC phase increases } \\
\text { and the time spent in HOC phase } \\
\text { decreases. Reduced dilution rate } \\
\text { is similar to reducing the glucose } \\
\text { concentration available for } \\
\text { growth. }\end{array}$ & 35 \\
\hline $\begin{array}{l}\text { Higher glucose } \\
\text { concentration }\end{array}$ & Decreases YMC period & See above. & 43 \\
\hline Phenelzine & Increases YMC period & $\begin{array}{l}\text { Antidepressant; Doubles length of } \\
\text { LOC phase }\end{array}$ & 40 \\
\hline cys4 3' UTR $\Delta$ & Abolished & $\begin{array}{l}\text { Cystathionine } \beta \text {-synthase, } \\
\text { converts homocysteine to } \\
\text { cystathionine, the only enzyme of } \\
\text { the sulphur metabolism pathway } \\
\text { required for the YMC. Expressed } \\
\text { in HOC phase when levels of } \\
\text { cystathionine show peak levels. }\end{array}$ & 22 \\
\hline urm1 $1 \Delta$ & $\begin{array}{l}\text { Unstable YMC with } \\
\text { decreased period }\end{array}$ & $\begin{array}{l}\text { Required for tRNA thiolation } \\
\left(\mathrm{mcm}^{5} \mathrm{~s}^{2} \mathrm{U}_{34}\right) \text {. Ubiquitin-like } \\
\text { protein involved in thiolation of } \\
\text { cytoplasmic tRNAs; receives } \\
\text { sulphur from the E1-like enzyme } \\
\text { Uba4 and transfers it to tRNA; } \\
\text { deletion shows increased } \\
\text { chronological lifespan. }\end{array}$ & 59 \\
\hline ahp1D & No change in periodicity & $\begin{array}{l}\text { Protein thiolation; Thiol-specific } \\
\text { peroxiredoxin; reduces } \\
\text { hydroperoxides to protect against } \\
\text { oxidative damage; function in vivo } \\
\text { requires covalent conjugation to } \\
\text { Urm1. }\end{array}$ & 59 \\
\hline $\begin{array}{l}\text { uba4 } \\
\text { uba4C397A } \\
\text { uba4C225A }\end{array}$ & $\begin{array}{l}\text { Unstable YMC with } \\
\text { decreased period }\end{array}$ & $\begin{array}{l}\text { Required for tRNA thiolation } \\
\left(\mathrm{mcm}^{5} \mathrm{~s}^{2} \mathrm{U}\right) . \text { E1-like protein that } \\
\text { activates Urm1 before urmylation; } \\
\text { also acts in thiolation of the } \\
\text { wobble base of cytoplasmic tRNAs } \\
\text { by adenylating and then thiolating } \\
\text { Urm1; deletion shows increased } \\
\text { chronological lifespan. }\end{array}$ & 59 \\
\hline $\operatorname{trm9\Delta }$ & $\begin{array}{l}\text { Near-normal YMC } \\
\text { period }\end{array}$ & $\begin{array}{l}\text { Required for } \mathrm{mcm}^{5} \text {-modified } \\
\text { uridines. tRNA methyltransferase; } \\
\text { catalyzes modification of wobble } \\
\text { bases in tRNA anticodons to } 2,5 \text { - } \\
\text { methoxycarbonylmethyluridine } \\
\text { (mcm) and 5- } \\
\text { methoxycarbonylmethyl-2- }\end{array}$ & 59 \\
\hline
\end{tabular}




\begin{tabular}{|c|c|c|c|}
\hline & & thiouridine & \\
\hline uba4 $\Delta$ trm9 & $\begin{array}{l}\text { Unstable YMC with very } \\
\text { short period }\end{array}$ & $\begin{array}{l}\text { Strain lacks both tRNA uridine } \\
\text { modifications }\left(\mathrm{mcm}^{5} \mathrm{~s}^{2} \mathrm{U} \text { and }\right. \\
\left.\mathrm{mcm}^{5} \mathrm{U}\right)\end{array}$ & \\
\hline elp3 & $\begin{array}{l}\text { Near-normal YMC } \\
\text { period }\end{array}$ & $\begin{array}{l}\text { Required for } \mathrm{mcm}^{5} \text {-modified } \\
\text { uridines. Subunit of Elongator } \\
\text { complex; Elongator is required for } \\
\text { modification of wobble } \\
\text { nucleosides in tRNA. }\end{array}$ & 59 \\
\hline uba $4 \Delta$ elp $3 \Delta$ & Abolishes YMC & $\begin{array}{l}\text { Strain lacks both tRNA uridine } \\
\text { modifications }\left(\mathrm{mcm}^{5} \mathrm{~s}^{2} \mathrm{U} \text { and }\right. \\
\left.\mathrm{mcm}^{5} \mathrm{U}\right) \text {. }\end{array}$ & \\
\hline$n \operatorname{cs} 2 \Delta$ & $\begin{array}{l}\text { Unstable YMC with } \\
\text { decreased period }\end{array}$ & $\begin{array}{l}\text { Specific tRNA uridine thiolation } \\
\text { defect not required for protein } \\
\text { urmylation }\end{array}$ & 59 \\
\hline$n \operatorname{cs} 6 \Delta$ & $\begin{array}{l}\text { Unstable YMC with } \\
\text { decreased period }\end{array}$ & $\begin{array}{l}\text { Specific tRNA uridine thiolation } \\
\text { defect not required for protein } \\
\text { urmylation }\end{array}$ & 59 \\
\hline$z w f 1 \Delta$ & Abolished & $\begin{array}{l}\text { Glucose-6-phosphate } \\
\text { dehydrogenase, catalyses the first } \\
\text { step of the pentose phosphate } \\
\text { pathway (PPP), deletion cannot } \\
\text { use the PPP to synthesize NADPH, } \\
\text { a key cycling metabolite and } \\
\text { antioxidant that peaks during the } \\
\text { HOC phase of the YMC. Levels of } \\
\text { the anti-oxidant NADPH increase } \\
\text { with levels of exogenous } \\
\text { methionine. Thus methionine is } \\
\text { likely to manifest its anti-ageing } \\
\text { properties via increased NADPH. }\end{array}$ & 22 \\
\hline
\end{tabular}


336 References

337

338 
Figure 1. Factors that contribute to biological rhythms and cycles. Alternative phases of oxidative and reductive metabolism (Redox) are at the core of most rhythms and cycles. Three interacting oscillators contribute to maintenance of the rhythm or cycle. These include cycling 342 metabolites, biochemical oscillators, often subject to rhythmic post-translational modifications, 343 and gene expression oscillations.

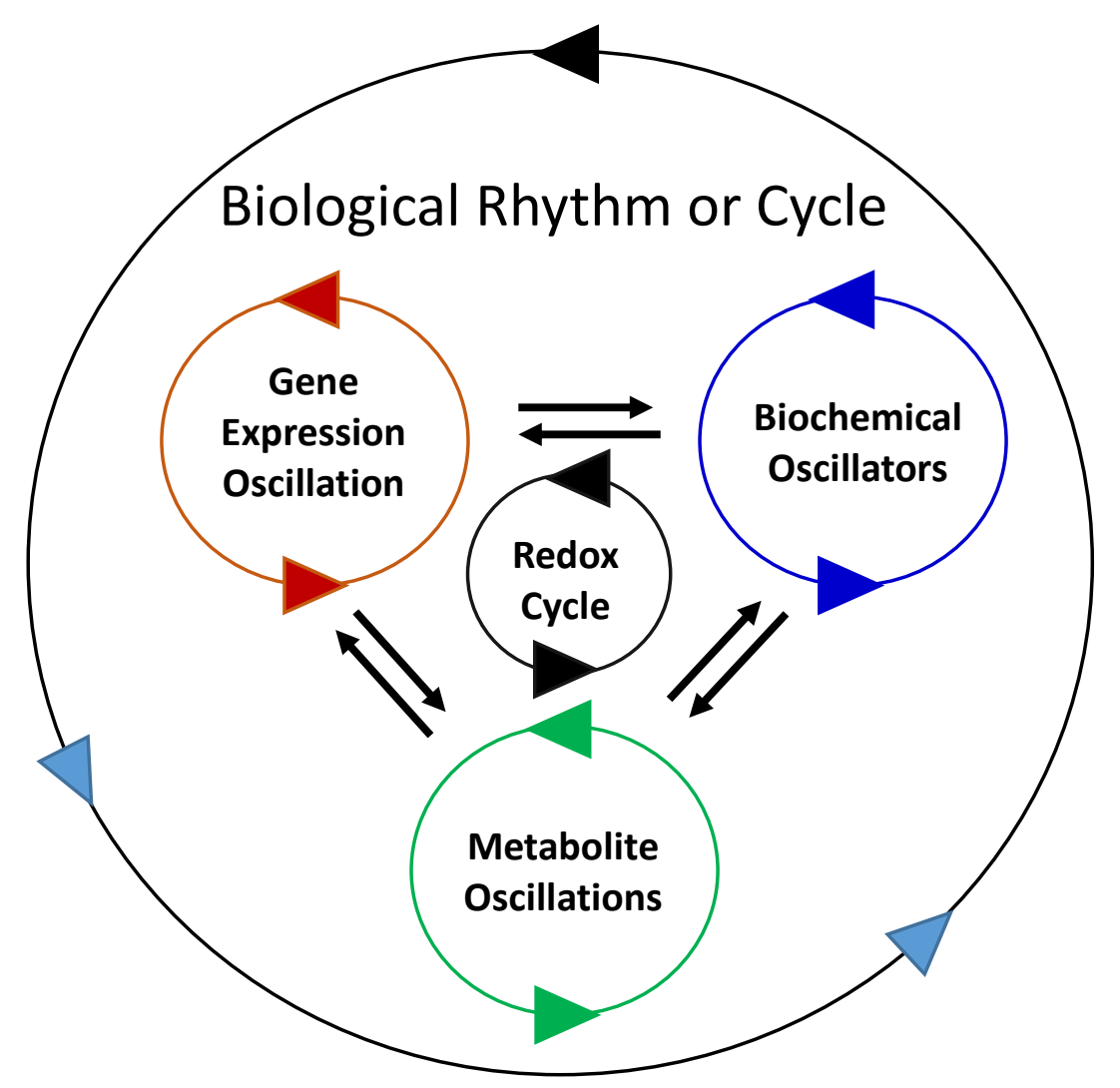


Figure 2. Metabolic cycles in S.cerevisiae. A Cycling metabolites during the YMC. The YMC is assessed by the concentration of dissolved oxygen $\left[\mathrm{dO}_{2}\right]$ in the medium shown for three cycles of the long phase metabolic cycle ( $\approx 300$ minutes each cycle). Metabolites such as acetyl CoA (blue), and the ATP to ADP ratio (red), also vary throughout the YMC, peaking antiphase to the levels of dissolved oxygen in the medium (black). Adapted from Machne and Murray $2012^{42}$ and Cai et al. ${ }^{37}$ B Cycling transcripts during the YMC. Top panel: Alternative phases of high oxygen consumption ( $\mathrm{HOC}$, pink) or low oxygen consumption (LOC, blue) during the YMC, assessed as $\%$ of saturated $\mathrm{O}_{2}$ concentration. Middle and Bottom panels: Cycling transcripts in the long phase metabolic cycle show peak levels in the HOC or the LOC, segregating into two large superclusters, divided by solid lines. Using gene ontology, the superclusters can be sub-clustered into 7 groups that are shared between the long ${ }^{31}$ and short metabolic cycles $^{30}$. These sub-clusters are shown in different colours with the average profile for each sub-cluster shown in the bottom panel. Three main phases of cycling transcripts are evident, two in the HOC, divided by dashed line, and one in the LOC. These are the transcript groups define by Tu et al ${ }^{31}$ as oxidative (OX) - the first subgroup of the HOC phase, reductive/building (RB) - the second subgroup of the HOC phase, and reductive/charging $(\mathrm{RC})$ - the LOC phase. Note that the terms used to describe the three main phases of cycling transcripts by Tu et al. $2005^{31}$, do not reflect the redox state of the cell in terms of differential oxygen uptake into the cell or its metabolism. Data taken from Tu et al. $2005^{31}$, and analysed by Machne and Murray $2012^{42}$. Taken and adapted from Machne and Murray $2012^{42}$.

A

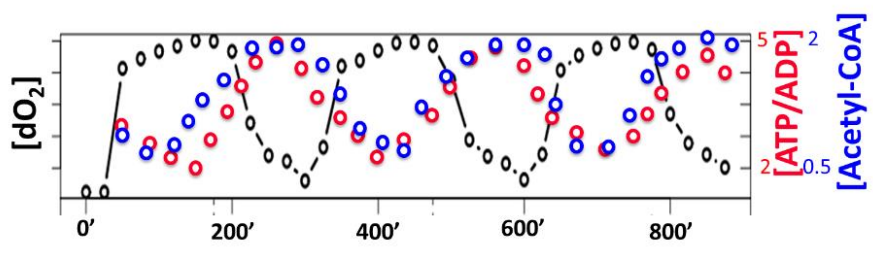

B

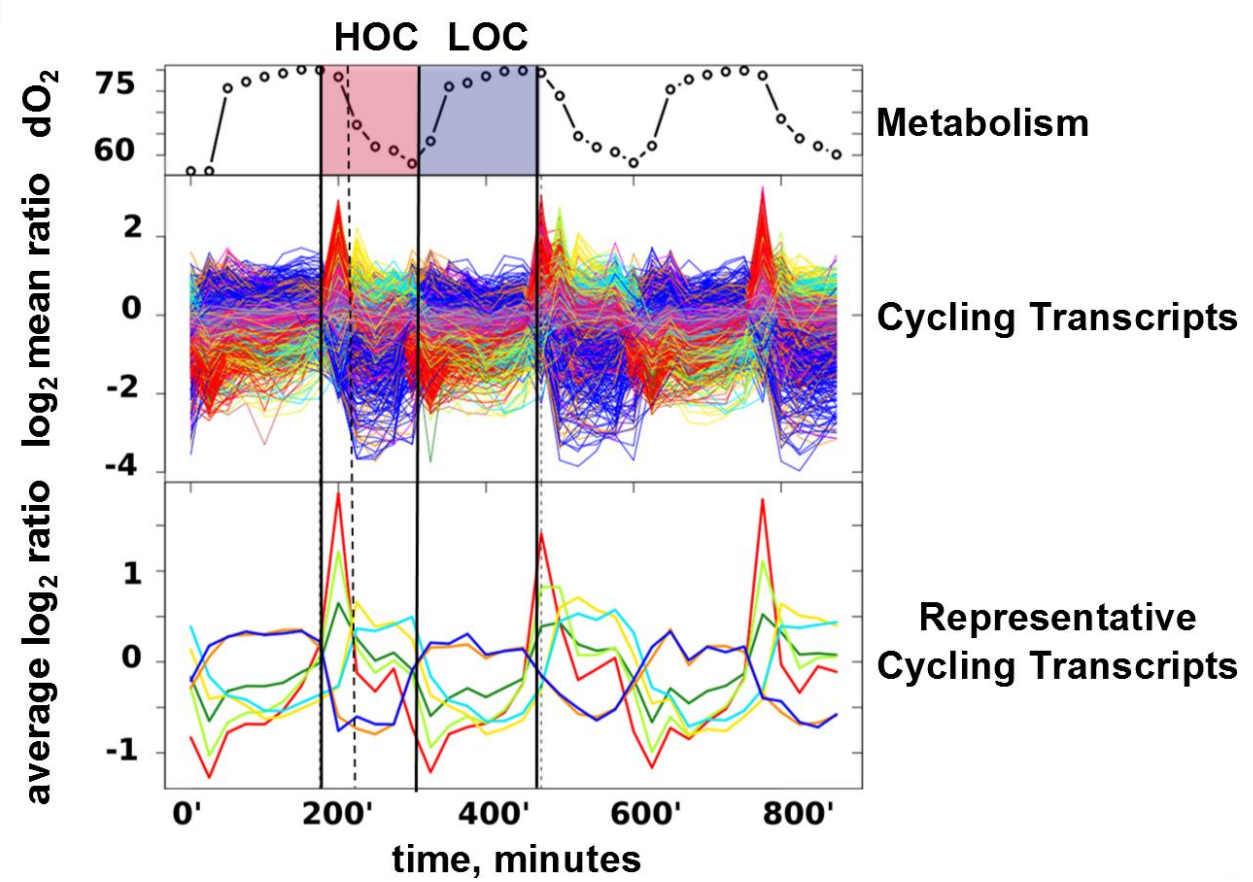


380 Figure 3 Coupling of growth rate, metabolic cycling, the cell division cycle and gene expression. A

381 Schematic showing events in cells as they cycle through the YMC and the CDC. Cells are colour-coded

382 to reflect their YMC phase (red and pink, HOC phase; blue, LOC). In each cell mitochondria (white

383 oblongs), the nucleus (blue) and ribosomes (orange) are indicated. Two growth phases are shown,

384 followed by an optional CDC and then the phase of quiescence, repair and stress resistance during

385 LOC. Growth 1 is equivalent to the OX phase, Growth 2 to the RB phase and Quiescence to the RC

386 phase defined by Tu et al. $2005^{31}$. B Schematic showing events in individual cells in a population over

387 time. Cells show metabolic cycling periodically leave the YMC and enter the CDC, as shown in A. Note

388 in order to maintain a synchronous population of metabolically cycling cells, the length of the CDC

389 should equal that of the YMC. The proportions of cells in HOC and LOC phases are related to growth

390 rate. Note that many gene deletions (unrelated to the YMC or CDC) that have an indirect effect on

391 growth rate (slow growth phenotype) will influence the proportions of cells in the HOC or LOC phase

392 and thus levels of transcripts expressed from the genes that are expressed in these phases, even in

393 exponential batch culture. Adapted from Slavov et al. ${ }^{32}$. C Refined analysis of patterns of cycling

394 transcripts during the YMC, proposed by Kuang et al. $2014^{41}$. One cycle of the long phase YMC showing

$395 \mathrm{dO}_{2}$ in the medium against time of sampling for RNA-seq analysis (1-16), colour coded according to the

396 phases of Tu et al. $2005^{31}$ and refined by Kuang et al. 2014 ${ }^{41}$. Clusters of peak transcript levels, relative

397 to the sampling point (1-16), and the phase of gene expression, clustered by Gene Ontology (GO), are

398 colour coded as for $\mathbf{A}$ and $\mathbf{B}$. Adapted from Kuang et al. ${ }^{41}$. 
A

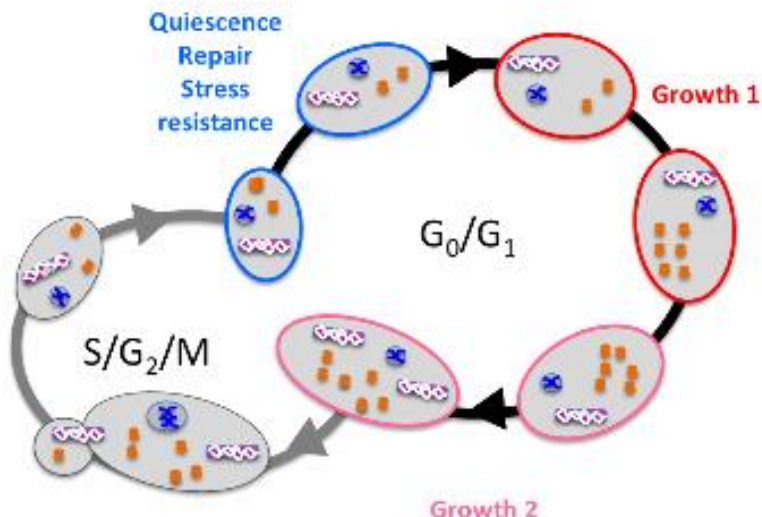

Growth 2

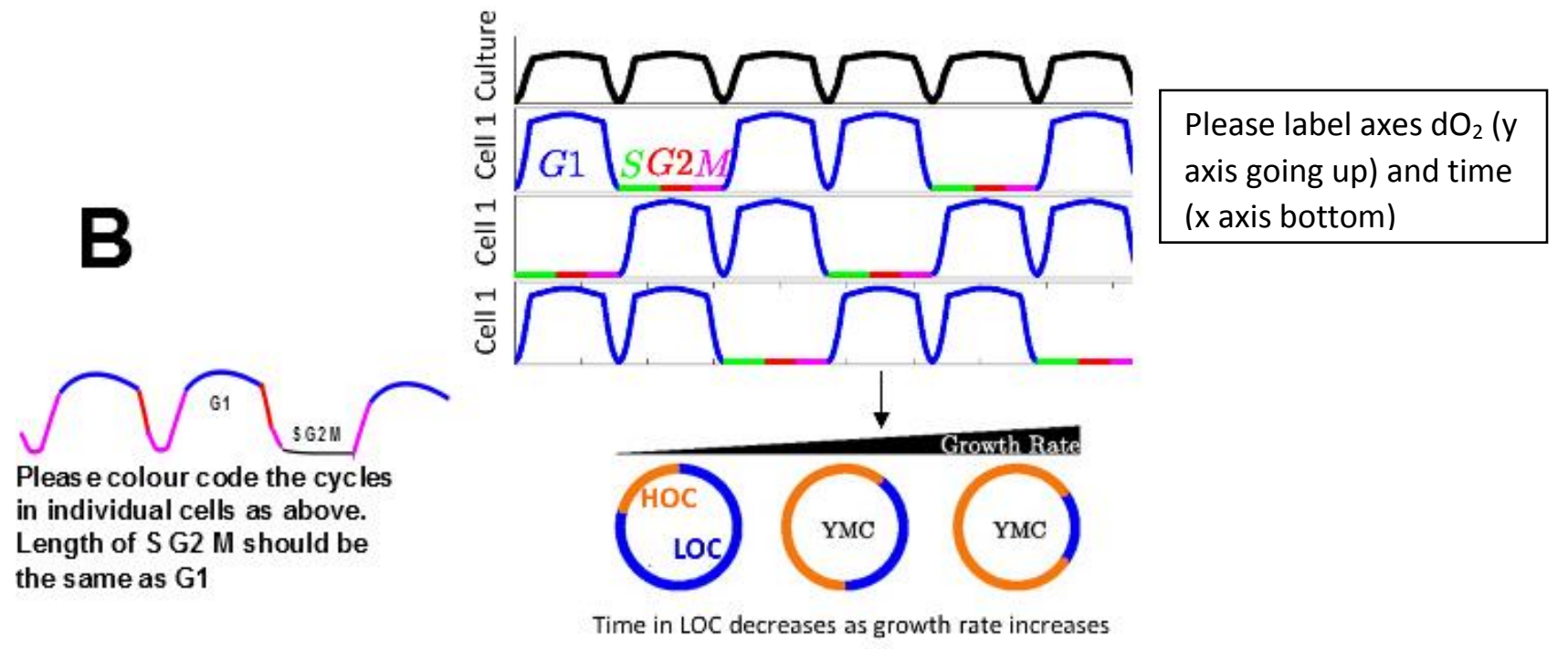

Please colour code the HOC red/pi and the LOC blue resp.

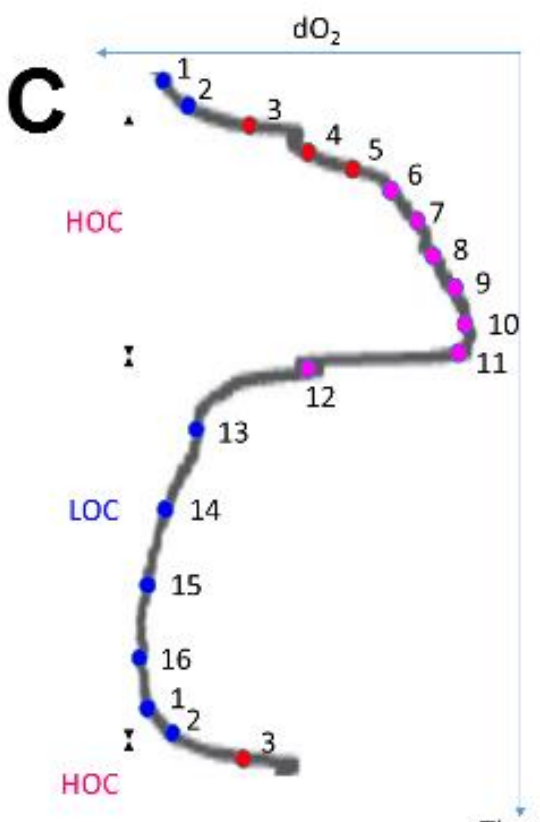

Peak cycling transcript sub-clusters and enriched GO

3-4 OX1 Ribosome biogenesis; RNA modification

4-5 OX2 Ribosomal protein; amino acid metabolism; regula

6-10 RB1 Cell cycle; DNA replication; DNA repair

7-12 RB2 Mitochondrial organisation, ribosomal proteins an

8-12 RB3 Respiration; mitochondrial envelope; generation c

12-16 RC1 Mitochondrial organisation and envelope; cytoske

13-2 RC2 Peroxisomes; vacuole; membrane invagination; re

16-2 RC3 Response to DNA damage 
This figure can be re-drawn in the journal style. Taken from Nguyen et al. 2014. Perhaps colour RPS4A and HMS2 genes and transcripts red/pink (and the double arrow promoter currently in blue) as they are OX genes and BAT2 and YJR149W genes and transcripts blue (and the double arrow promoter driving BAT2 and SUT650 (HMS2 antisense transcript) currently in orange) as these are RC genes or whatever colours are chosen for the phases.
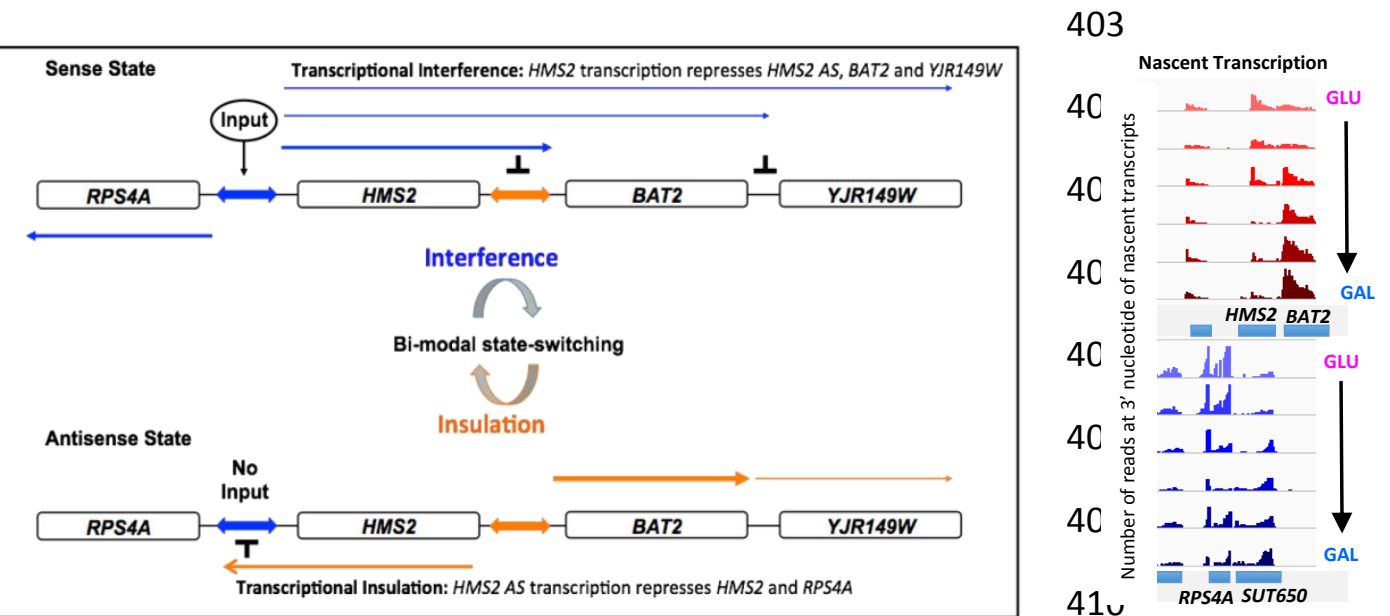

Figure 4: Transcriptional state-switching at YMC-regulated genes Right Model for state-switching between a sense-dominant state and an antisense-dominant state by transcription factors (Input) at the divergent promoters between RPS4A and HMS2 (blue double arrow) and HMS2 AS (SUT650) and BAT2 (orange double arrow). RPS4A and HMS2 are expressed during the OX phase of the YMC and in glucose. $B A T 2$ and YJR149W are expressed during the RC phase and in galactose. During growth in glucose, cells cycle between the sense-dominant state and the antisense-dominant state with the majority of cells existing in the sense-dominant state. During growth in galactose, cells cycle between the sensedominant state and the antisense-dominant state with the majority of cells existing in the antisensedominant state. In the YMC, the sense state is present during the OX phase and the antisense state during the RC phase. The antisense state is so called as the HMS2 locus is transcribed in the antisense direction to produce the transcript known as SUT650. The net effect is repression of the divergent promoter between RPS4A and HMS2 sense and insulation of the BAT2 and YJR149W gene promoters from transcriptional interference from transcription events arising at the HMS2 sense promoter. Transcription proceeds over the BAT2 promoter, repressing expression by converting the chromatin structure to one that is not permissive for transcriptional initiation, via deposition of H3K36me3. In addition, bi-cistronic and tri-cistronic transcripts extend through BAT2 into YJR149W, repressing its expression. Thus transcription itself is used to regulate transcription. Adapted from Nguyen et al. $2014^{15}$. Left Nascent transcription assessed using NET-seq ${ }^{15}$ over RPS4A, HMS2 and BAT2 during the switch from glucose $(G L U)$ to galactose (GAL) reveals the state switch. Genes (blue boxes) and NET-seq reads for the Watson strand are shown in reds and for the Crick strand in blues. The GLU to GAL shift recapitulates the transition from the OX phase to the RC phase of the YMC. Samples are taken during growth in glucose and at 0 , (to control for stress of changing medium) 5, 15, 60, and 180 minutes after transfer to galactose. Note (i) RPS4A has gaps in the sequence reads due to homology with other regions of the genome, (ii) reads over the BAT2 promoter in glucose and (iii) reads from SUT650 extending over the RPS4A and HMS2 divergent promoter as cells spend time in galactose. 
439 1. Pattanayak, G. \& Rust, M.J. The cyanobacterial clock and metabolism. Curr Opin Microbio/ 18, 90-

$440 \quad 5$ (2014).

441 2. Ray, S. \& Reddy, A.B. Cross-talk between circadian clocks, sleep-wake cycles, and metabolic

442

443

444

445

446

447

448

449

450 networks: Dispelling the darkness. Bioessays 38, 394-405 (2016).

3. Edgar, R.S. et al. Peroxiredoxins are conserved markers of circadian rhythms. Nature 485, 459-64 (2012).

4. Tomita, J., Nakajima, M., Kondo, T. \& Iwasaki, H. No transcription-translation feedback in circadian rhythm of KaiC phosphorylation. Science 307, 251-4 (2005).

5. O'Neill, J.S. \& Reddy, A.B. Circadian clocks in human red blood cells. Nature 469, 498-503 (2011).

6. Causton, H.C., Feeney, K.A., Ziegler, C.A. \& O'Neill, J.S. Metabolic Cycles in Yeast Share Features Conserved among Circadian Rhythms. Curr Biol 25, 1056-62 (2015).

7. Novak, B. \& Tyson, J.J. Design principles of biochemical oscillators. Nat Rev Mol Cell Biol 9, 98191 (2008).

451

452

453

454

455

456

457

458

459

460

461

462

463

464

465

466

467

468

469

470

471

472

473

474

475

476

477

478

479

480

481

482

483

484

485

486

487

488

489

490

491

8. Reddy, A.B. \& Rey, G. Metabolic and nontranscriptional circadian clocks: eukaryotes. Annu Rev Biochem 83, 165-89 (2014).

9. Schick, S. et al. Identifying Novel Transcriptional Regulators with Circadian Expression. Mol Cell Biol 36, 545-58 (2015).

10. Koike, N. et al. Transcriptional architecture and chromatin landscape of the core circadian clock in mammals. Science 338, 349-54 (2012).

11. Morf, J. et al. Cold-inducible RNA-binding protein modulates circadian gene expression posttranscriptionally. Science 338, 379-83 (2012).

12. Rodriguez, J. et al. Nascent-Seq analysis of Drosophila cycling gene expression. Proc Natl Acad Sci U S A 110, E275-84 (2013).

13. Hurley, J.M. et al. Analysis of clock-regulated genes in Neurospora reveals widespread posttranscriptional control of metabolic potential. Proc Natl Acad Sci U S A 111, 16995-7002 (2014).

14. Guo, J., Cheng, P., Yuan, H. \& Liu, Y. The exosome regulates circadian gene expression in a posttranscriptional negative feedback loop. Cell 138, 1236-46 (2009).

15. Nguyen, T. et al. Transcription mediated insulation and interference direct gene cluster expression switches. Elife 3, e03635 (2014).

16. Hendriks, G.J., Gaidatzis, D., Aeschimann, F. \& Grosshans, H. Extensive oscillatory gene expression during C. elegans larval development. Mol Cell 53, 380-92 (2014).

17. Robles, M.S., Cox, J. \& Mann, M. In-vivo quantitative proteomics reveals a key contribution of post-transcriptional mechanisms to the circadian regulation of liver metabolism. PLoS Genet 10, e1004047 (2014).

18. Jang, C., Lahens, N.F., Hogenesch, J.B. \& Sehgal, A. Ribosome profiling reveals an important role for translational control in circadian gene expression. Genome Res 25, 1836-47 (2015).

19. Janich, P., Arpat, A.B., Castelo-Szekely, V., Lopes, M. \& Gatfield, D. Ribosome profiling reveals the rhythmic liver translatome and circadian clock regulation by upstream open reading frames. Genome Res 25, 1848-59 (2015).

20. Lipton, J.O. et al. The Circadian Protein BMAL1 Regulates Translation in Response to S6K1Mediated Phosphorylation. Cell 161, 1138-51 (2015).

21. Murray, D.B., Beckmann, M. \& Kitano, H. Regulation of yeast oscillatory dynamics. Proc Natl Acad Sci U S A 104, 2241-6 (2007).

22. Tu, B.P. et al. Cyclic changes in metabolic state during the life of a yeast cell. Proc Natl Acad Sci U S A 104, 16886-91 (2007).

23. Mohler, R.E. et al. Identification and evaluation of cycling yeast metabolites in two-dimensional comprehensive gas chromatography-time-of-flight-mass spectrometry data. J Chromatogr A 1186, 401-11 (2008).

24. Dallmann, R., Viola, A.U., Tarokh, L., Cajochen, C. \& Brown, S.A. The human circadian metabolome. Proc Natl Acad Sci U S A 109, 2625-9 (2012).

25. Eckel-Mahan, K.L. et al. Coordination of the transcriptome and metabolome by the circadian clock. Proc Natl Acad Sci U S A 109, 5541-6 (2012). 
26. Ribas-Latre, A. \& Eckel-Mahan, K. Interdependence of nutrient metabolism and the circadian clock system: Importance for metabolic health. Mol Metab 5, 133-52 (2016).

27. Bass, J. Circadian topology of metabolism. Nature 491, 348-56 (2012).

28. Kaspar von Meyenburg, H. Energetics of the budding cycle of Saccharomyces cerevisiae during glucose limited aerobic growth. Arch Mikrobiol 66, 289-303 (1969).

29. Murray, D.B., Roller, S., Kuriyama, H. \& Lloyd, D. Clock control of ultradian respiratory oscillation found during yeast continuous culture. J Bacteriol 183, 7253-9 (2001).

30. Klevecz, R.R., Bolen, J., Forrest, G. \& Murray, D.B. A genomewide oscillation in transcription gates DNA replication and cell cycle. Proc Natl Acad Sci U S A 101, 1200-5 (2004).

31. Tu, B.P., Kudlicki, A., Rowicka, M. \& McKnight, S.L. Logic of the yeast metabolic cycle: temporal compartmentalization of cellular processes. Science 310, 1152-8 (2005).

32. Slavov, N., Macinskas, J., Caudy, A. \& Botstein, D. Metabolic cycling without cell division cycling in respiring yeast. Proc Natl Acad Sci U S A 108, 19090-5 (2011).

33. Slavov, N. \& Botstein, D. Coupling among growth rate response, metabolic cycle, and cell division cycle in yeast. Mol Biol Cell 22, 1997-2009 (2011).

34. Muller, D., Exler, S., Aguilera-Vazquez, L., Guerrero-Martin, E. \& Reuss, M. Cyclic AMP mediates the cell cycle dynamics of energy metabolism in Saccharomyces cerevisiae. Yeast 20, 351-67 (2003).

35. Burnetti, A.J., Aydin, M. \& Buchler, N.E. Cell cycle Start is coupled to entry into the yeast metabolic cycle across diverse strains and growth rates. Mol Biol Cell 27, 64-74 (2016).

36. Zhao, G., Chen, Y., Carey, L. \& Futcher, B. Cyclin-Dependent Kinase Co-Ordinates Carbohydrate Metabolism and Cell Cycle in S. cerevisiae. Mol Cell 62, 546-57 (2016).

37. Cai, L., Sutter, B.M., Li, B. \& Tu, B.P. Acetyl-CoA induces cell growth and proliferation by promoting the acetylation of histones at growth genes. Mol Cell 42, 426-37 (2011).

38. Sohn, H.Y., Murray, D.B. \& Kuriyama, H. Ultradian oscillation of Saccharomyces cerevisiae during aerobic continuous culture: hydrogen sulphide mediates population synchrony. Yeast $16,1185-$ 90 (2000).

39. Murray, D.B., Klevecz, R.R. \& Lloyd, D. Generation and maintenance of synchrony in Saccharomyces cerevisiae continuous culture. Exp Cell Res 287, 10-5 (2003).

40. Li, C.M. \& Klevecz, R.R. A rapid genome-scale response of the transcriptional oscillator to perturbation reveals a period-doubling path to phenotypic change. Proc Natl Acad Sci U S A 103, 16254-9 (2006).

41. Kuang, Z. et al. High-temporal-resolution view of transcription and chromatin states across distinct metabolic states in budding yeast. Nat Struct Mol Biol 21, 854-63 (2014).

42. Machne, R. \& Murray, D.B. The yin and yang of yeast transcription: elements of a global feedback system between metabolism and chromatin. PLoS One 7, e37906 (2012).

43. Wang, G.Z. et al. Cycling Transcriptional Networks Optimize Energy Utilization on a Genome Scale. Cell Rep 13, 1868-80 (2015).

44. Amariei, C., Tomita, M. \& Murray, D.B. Quantifying periodicity in omics data. Front Cell Dev Biol 2, 40 (2014).

45. Putker, M. \& O'Neill, J.S. Reciprocal Control of the Circadian Clock and Cellular Redox State - a Critical Appraisal. Mol Cells 39, 6-19 (2016).

46. Hurley, J.M., Loros, J.J. \& Dunlap, J.C. The circadian system as an organizer of metabolism. Fungal Genet Biol (2015).

47. Panda, S. et al. Coordinated transcription of key pathways in the mouse by the circadian clock. Cell 109, 307-20 (2002).

48. Claridge-Chang, A. et al. Circadian regulation of gene expression systems in the Drosophila head. Neuron 32, 657-71 (2001).

49. Lloyd, D. \& Murray, D.B. Ultradian metronome: timekeeper for orchestration of cellular coherence. Trends Biochem Sci 30, 373-7 (2005).

50. Li, S. \& Zhang, L. Circadian Control of Global Transcription. Biomed Res Int 2015, 187809 (2015).

51. Klevecz, R.R. \& Li, C.M. Evolution of the clock from yeast to man by period-doubling folds in the cellular oscillator. Cold Spring Harb Symp Quant Biol 72, 421-9 (2007). 
52. Tu, B.P. \& McKnight, S.L. Metabolic cycles as an underlying basis of biological oscillations. Nat Rev Mol Cell Biol 7, 696-701 (2006).

53. Zhang, L. et al. Dissociation of circadian and circatidal timekeeping in the marine crustacean Eurydice pulchra. Curr Biol 23, 1863-73 (2013).

54. Eelderink-Chen, Z., Olmedo, M., Bosman, J. \& Merrow, M. Using circadian entrainment to find cryptic clocks. Methods Enzymol 551, 73-93 (2015).

55. Eelderink-Chen, Z. et al. A circadian clock in Saccharomyces cerevisiae. Proc Natl Acad Sci U S A 107, 2043-7 (2010).

56. Paulose, J.K., Rucker, E.B., 3rd \& Cassone, V.M. Toward the beginning of time: circadian rhythms in metabolism precede rhythms in clock gene expression in mouse embryonic stem cells. PLoS One 7, e49555 (2012).

57. Murray, D.B., Engelen, F., Lloyd, D. \& Kuriyama, H. Involvement of glutathione in the regulation of respiratory oscillation during a continuous culture of Saccharomyces cerevisiae. Microbiology 145 ( Pt 10), 2739-45 (1999).

58. Keulers, M., Suzuki, T., Satroutdinov, A.D. \& Kuriyama, H. Autonomous metabolic oscillation in continuous culture of Saccharomyces cerevisiae grown on ethanol. FEMS Microbiol Lett 142, 253-8 (1996).

59. Laxman, S. et al. Sulfur amino acids regulate translational capacity and metabolic homeostasis through modulation of tRNA thiolation. Cell 154, 416-29 (2013).

60. Chen, Z., Odstrcil, E.A., Tu, B.P. \& McKnight, S.L. Restriction of DNA replication to the reductive phase of the metabolic cycle protects genome integrity. Science 316, 1916-9 (2007).

61. Futcher, B. Metabolic cycle, cell cycle, and the finishing kick to Start. Genome Biol 7, 107 (2006).

62. Brauer, M.J. et al. Coordination of growth rate, cell cycle, stress response, and metabolic activity in yeast. Mol Biol Cell 19, 352-67 (2008).

63. O'Duibhir, E. et al. Cell cycle population effects in perturbation studies. Mol Syst Biol 10, 732 (2014).

64. Stincone, A. et al. The return of metabolism: biochemistry and physiology of the pentose phosphate pathway. Biol Rev Camb Philos Soc (2014).

65. Campbell, K., Vowinckel, J., Keller, M.A. \& Ralser, M. Methionine Metabolism Alters Oxidative Stress Resistance via the Pentose Phosphate Pathway. Antioxid Redox Signal 24, 543-7 (2016).

66. Shi, L. \& Tu, B.P. Acetyl-CoA and the regulation of metabolism: mechanisms and consequences. Curr Opin Cell Biol 33, 125-31 (2015).

67. Friis, R.M. et al. Rewiring AMPK and mitochondrial retrograde signaling for metabolic control of aging and histone acetylation in respiratory-defective cells. Cell Rep 7, 565-74 (2014).

68. Shi, L. \& Tu, B.P. Acetyl-CoA induces transcription of the key G1 cyclin CLN3 to promote entry into the cell division cycle in Saccharomyces cerevisiae. Proc Natl Acad Sci U S A 110, 7318-23 (2013).

69. Nocetti, N. \& Whitehouse, I. Nucleosome repositioning underlies dynamic gene expression. Genes Dev 30, 660-72 (2016).

70. Weiner, A. et al. Systematic dissection of roles for chromatin regulators in a yeast stress response. PLoS Biol 10, e1001369 (2012).

71. Weiner, A. et al. High-Resolution Chromatin Dynamics during a Yeast Stress Response. Mol Cell 58, 371-86 (2015).

72. Parnell, T.J., Schlichter, A., Wilson, B.G. \& Cairns, B.R. The chromatin remodelers RSC and ISW1 display functional and chromatin-based promoter antagonism. Elife 4, e06073 (2015).

73. Downey, M. et al. Gcn5 and sirtuins regulate acetylation of the ribosomal protein transcription factor Ifh1. Curr Biol 23, 1638-48 (2013).

74. Kim, J.H., Saraf, A., Florens, L., Washburn, M. \& Workman, J.L. Gen5 regulates the dissociation of SWI/SNF from chromatin by acetylation of Swi2/Snf2. Genes Dev 24, 2766-71 (2010).

75. Galdieri, L., Zhang, T., Rogerson, D. \& Vancura, A. Reduced Histone Expression or a Defect in Chromatin Assembly Induces Respiration. Mol Cell Biol 36, 1064-77 (2016).

76. Hsieh, T.H. et al. Mapping Nucleosome Resolution Chromosome Folding in Yeast by Micro-C. Cell 162, 108-19 (2015). 
77. Ioshikhes, I.P., Albert, I., Zanton, S.J. \& Pugh, B.F. Nucleosome positions predicted through comparative genomics. Nat Genet 38, 1210-5 (2006).

78. Segal, E. et al. A genomic code for nucleosome positioning. Nature 442, 772-8 (2006).

79. Menet, J.S., Pescatore, S. \& Rosbash, M. CLOCK:BMAL1 is a pioneer-like transcription factor. Genes Dev 28, 8-13 (2014).

80. Rodriguez, J., Menet, J.S. \& Rosbash, M. Nascent-seq indicates widespread cotranscriptional RNA editing in Drosophila. Mol Cell 47, 27-37 (2012).

81. Kadener, S., Menet, J.S., Schoer, R. \& Rosbash, M. Circadian transcription contributes to core period determination in Drosophila. PLoS Biol 6, e119 (2008).

82. Rao, A.R. \& Pellegrini, M. Regulation of the yeast metabolic cycle by transcription factors with periodic activities. BMC Syst Biol 5, 160 (2011).

83. Keogh, M.-C. et al. Cotranscriptional Set2 Methylation of Histone H3 Lysine 36 Recruits a Repressive Rpd3 Complex. Cell 123, 593-605 (2005).

84. Carrozza, M.J. et al. Histone $\mathrm{H} 3$ methylation by Set2 directs deacetylation of coding regions by Rpd3S to suppress spurious intragenic transcription. Cell 123, 581-92 (2005).

85. Sun, G. et al. Suppression of WHITE COLLAR-independent frequency Transcription by Histone H3 Lysine 36 Methyltransferase SET-2 Is Necessary for Clock Function in Neurospora. J Biol Chem (2016).

86. Xue, Z. et al. Transcriptional interference by antisense RNA is required for circadian clock function. Nature 514, 650-3 (2014).

87. Vollmers, C. et al. Circadian oscillations of protein-coding and regulatory RNAs in a highly dynamic mammalian liver epigenome. Cell Metab 16, 833-45 (2012).

88. Menet, J.S., Rodriguez, J., Abruzzi, K.C. \& Rosbash, M. Nascent-Seq reveals novel features of mouse circadian transcriptional regulation. Elife 1, e00011 (2012).

89. Sauman, I. \& Reppert, S.M. Circadian clock neurons in the silkmoth Antheraea pernyi: novel mechanisms of Period protein regulation. Neuron 17, 889-900 (1996).

90. Swiezewski, S., Liu, F., Magusin, A. \& Dean, C. Cold-induced silencing by long antisense transcripts of an Arabidopsis Polycomb target. Nature 462, 799-802 (2009).

91. Murray, S.C. et al. Sense and antisense transcription are associated with distinct chromatin architectures across genes. Nucleic Acids Res 43, 7823-37 (2015).

92. Mellor, J., Woloszczuk, R. \& Howe, F.S. The Interleaved Genome. Trends Genet 32, 57-71 (2016).

93. Nagoshi, E. et al. Circadian gene expression in individual fibroblasts: cell-autonomous and selfsustained oscillators pass time to daughter cells. Cell 119, 693-705 (2004).

94. Chen, Z. \& McKnight, S.L. A conserved DNA damage response pathway responsible for coupling the cell division cycle to the circadian and metabolic cycles. Cell Cycle 6, 2906-12 (2007).

95. Kippert, F. \& Lloyd, D. A temperature-compensated ultradian clock ticks in Schizosaccharomyces pombe. Microbiology 141 ( Pt 4), 883-90 (1995).

96. Izumo, M., Johnson, C.H. \& Yamazaki, S. Circadian gene expression in mammalian fibroblasts revealed by real-time luminescence reporting: temperature compensation and damping. Proc Natl Acad Sci U S A 100, 16089-94 (2003).

97. Chin, S.L., Marcus, I.M., Klevecz, R.R. \& Li, C.M. Dynamics of oscillatory phenotypes in Saccharomyces cerevisiae reveal a network of genome-wide transcriptional oscillators. FEBS J 279, 1119-30 (2012).

98. Lloyd, D., Salgado, L.E., Turner, M.P., Suller, M.T. \& Murray, D. Cycles of mitochondrial energization driven by the ultradian clock in a continuous culture of Saccharomyces cerevisiae. Microbiology 148, 3715-24 (2002).

99. Kwak, W.J., Kwon, G.S., Jin, I., Kuriyama, H. \& Sohn, H.Y. Involvement of oxidative stress in the regulation of $\mathrm{H}(2) \mathrm{S}$ production during ultradian metabolic oscillation of Saccharomyces cerevisiae. FEMS Microbiol Lett 219, 99-104 (2003).

100. Sohn, H.Y., Kum, E.J., Kwon, G.S., Jin, I. \& Kuriyama, H. Regulation of branched-chain, and sulfurcontaining amino acid metabolism by glutathione during ultradian metabolic oscillation of Saccharomyces cerevisiae. J Microbiol 43, 375-80 (2005). 
101. Ouyang, Y., Xu, Q., Mitsui, K., Motizuki, M. \& Xu, Z. PSK2 coordinates glucose metabolism and utilization to maintain ultradian clock-coupled respiratory oscillation in Saccharomyces cerevisiae yeast. Arch Biochem Biophys 509, 52-8 (2011).

102. Peek, C.B. et al. Circadian clock NAD+ cycle drives mitochondrial oxidative metabolism in mice. Science 342, 1243417 (2013).

103. Cho, C.S., Yoon, H.J., Kim, J.Y., Woo, H.A. \& Rhee, S.G. Circadian rhythm of hyperoxidized peroxiredoxin II is determined by hemoglobin autoxidation and the $20 \mathrm{~S}$ proteasome in red blood cells. Proc Natl Acad Sci U S A 111, 12043-8 (2014).

104. Milev, N.B. et al. Analysis of the redox oscillations in the circadian clockwork. Methods Enzymol 552, 185-210 (2015).

105. O'Neill, J.S. \& Feeney, K.A. Circadian redox and metabolic oscillations in mammalian systems. Antioxid Redox Signal 20, 2966-81 (2014).

106. Naruse, Y. et al. Circadian and light-induced transcription of clock gene Per1 depends on histone acetylation and deacetylation. Mol Cell Biol 24, 6278-87 (2004).

107. Nakahata, Y. et al. The NAD+-dependent deacetylase SIRT1 modulates CLOCK-mediated chromatin remodeling and circadian control. Cell 134, 329-40 (2008).

108. Fogg, P.C. et al. Class lla histone deacetylases are conserved regulators of circadian function. $J$ Biol Chem 289, 34341-8 (2014).

109. Aguilar-Arnal, L. et al. Cycles in spatial and temporal chromosomal organization driven by the circadian clock. Nat Struct Mol Biol 20, 1206-13 (2013).

110. Welsh, D.K., Yoo, S.H., Liu, A.C., Takahashi, J.S. \& Kay, S.A. Bioluminescence imaging of individual fibroblasts reveals persistent, independently phased circadian rhythms of clock gene expression. Curr Biol 14, 2289-95 (2004). 